\title{
To eat or not to eat-in the library
}

\author{
By Deborah D. Halsted
}

Assistant Director

Harrington Library of the

Health Sciences

\author{
and Dana M. Neeley
}

Associate Director

Texas Tech University Regional

Academic Health Center

\section{The food and drink debate is addressed in a recent survey.}

onsumption of food and beverages on

library premises is an almost universal problem facing librarians. The authors surveyed medical librarians in Texas, Arkansas, Louisiana, Oklahoma, and New Mexico to ascertain how other libraries deal with the problem. Results of the survey indicate that a) even if neither food nor drink is officially allowed, patrons will surreptitiously bring both in anyway, making it more difficult to control insects and mice, b) allowing food and drink in employee areas makes enforcing a no-food-ordrink policy in public areas more difficult because patrons see a double standard, and c) hospital libraries, which tend to be smaller than academic medical libraries, allow food and drink more often, sometimes as a marketing tool.

\section{Method}

This paper reports on how medical libraries in a five state region deal with the problem of food and beverage consumption on library premises. Of 238 surveys mailed, 121 completed surveys were returned; 86 were from hospital libraries, 20 from academic medical libraries, and 15 from other types of libraries. Sixty-six percent of the respondents expressed interest in seeing the survey results, affirming that the problem of eating and drinking in libraries is prevalent.

\section{Discussion and results (food)}

Of the 121 librarians completing the survey, only 14 percent responded that food is absolutely not allowed anywhere in the library. The remaining 104 librarians said that food is allowed, with almost 40 percent of these librarians indicating that food is permitted in all areas of the library, and 46 percent indicating that it is allowed only in some areas. The majority of those who allow food in restricted areas permit it in employee lounges and employee work areas; yet other areas respondents mentioned for

...if patrons are found in the

computer room with food or beverages, their names are taken and they are forbidden to ever use the room again.

food consumption included conference rooms and workstations or carrels. Two librarians emphasized that food is allowed everywhere in the library except near the computers or audiovisuals. A number of librarians from all three categories stressed that food is not allowed anywhere in the library, not even in employee work areas; having such a strict, inclusive policy is an effective deterrent for patrons bringing in food because it eliminates perceptions of a double standard. One academic librarian stated that library patrons sometimes request to use the staff lounge, but it was not revealed whether such requests were granted.

Many librarians added both positive and negative comments concerning food consumption in the 
library. A number of librarians in Dallas, New Orleans, San Antonio, and Oklahoma City indicated that they have had a problem with either insects (ants and cockroaches) or mice. The librarians with these problems were often those in which food is prohibited, butin which patrons have sneaked the food in and left wrappers, cups, or pieces of popcorn behind. One librarian stated that if patrons are found in the library with food, they are asked to leave and, more severely, if patrons are found in the computer room with food or beverages, their names are taken and they are forbidden to ever use the room again. On the other hand, some librarians, especially in small hospital libraries, allow food and drink in the library, using the privilege as a marketing tool. Either morning rounds are held in the library over coffee and sweet rolls, or staff members are encouraged to eat lunch in the library. While

\section{... one librarian abandoned rules restricting food because there is never any control over what happens to books when they circulate.}

most librarians have made the decisions concerning food and beverages on library premises, hospital administrators often dictate the rules. For example, one hospital library is an extension of a meeting room. When there is a large meeting, the room's walls are moved back to utilize library space, so if there is food at the meeting it is out of the librarian's control.

Many librarians noted that because it has always been so difficult to keep food and drink out of libraries, a special room, away from computers, has been provided where patrons may eat and drink while reading the current journals. Finally, one librarian abandoned rules restricting food because there is never any control over what happens to books when they circulate.

\section{Discussion and results (drink)}

Of the 121 respondents, approximately seven percent said that drinks are absolutely forbidden anywhere in the library, 43 percent indicated that drinks are allowed in all areas of the library, and 50 percent said they were allowed in restricted areas only. Again, the largest majority allow drinks in employee lounges and employee work areas. The other areas are the same as for food. One hospital librarian allows only water at employee desks.

Many librarians made additional comments similar to those concerning food. Many hospital librar- ians offer coffee either free or for a small price as a promotional device. One librarian donates coffee proceeds to the Children's Miracle Network.

One academic medical librarian responded that beverages are allowed everywhere in the library if brought in "non-spillable" or "sip-it" containers with straws. This library allows food only in employee offices, which are not viewable to the public. A number of completed surveys indicated there are spills in the library regardless of having rules concerning drinks.

\section{Conclusions}

A number of conclusions can be drawn from the survey responses. First, the question of allowing food or beverages in libraries appears to affect all types and sizes of health science libraries. Second, even if neither is officially allowed, it seems to be inevitable that patrons will surreptitiously bring food and drink in, often making it more difficult to control insects and mice. Third, if food and drink are allowed in employee areas, which is common, it is more difficult to restrict patrons who see a double standard in library policy. Fourth, smaller libraries, especially hospital libraries, seem to have more flexible rules. Allowing food and drink is often used as a promotional tool to bring patrons in during lunch or rounds. Because the hospital library is usually smaller than an academic or special library, spills and messes are easier to spot and clean up quickly.

'Since this paper was submitted, the Harrington Library of the Health Sciences has begun to allow drinks in the library. The only noticeable result has been delighted patrons who spend more time in the library.

\section{Tell us how academic libraries make a difference}

ALA is developing "power tools" for speakers as part of its Decade of the Librarian theme and of ALAPresident Pat Schuman's "Right to Know" campaign. To make sure academic libraries are represented, ACRL would like your stories, anecdotes, vignettes, quotations, facts, and figures regarding the importance of academic libraries and how academic librarians make a difference. These will be used for tip sheets, campaign books, speakers guides, and fact sheets. Send your stories to: Mary Taylor, ACRL, $50 \mathrm{E}$. Huron St., Chicago, IL 60611; (800) 545-2433 ext. 2515; bitnet: U55380@uicvm. 